\title{
Model zakupu produktów żywnościowych opatrzonych oświadczeniami żywieniowymi i zdrowotnymi
}

\section{Wstęp}

Zmiany na rynku produktów żywnościowych są wynikiem dążenia do zaspokojenia przeobrażających się potrzeb konsumentów. W świetle zachowań konsumenckich przejawiających się zwiększonymi zakupami produktów prozdrowotnych i suplementów diety, odpowiedzią producentów stało się wprowadzanie na rynek i popularyzacja żywności funkcjonalnej (produktów żywnościowych o właściwościach prozdrowotnych). Żywność ta obejmuje produkty zawierające oświadczenia żywieniowe i zdrowotne.

W dobie rozwoju chorób cywilizacyjnych oraz wzrostu dbałości o zdrowie konsumenci zmieniają swój sposób żywienia, czego rezultatem są, między innymi, poszukiwania żywności przynoszącej im określone korzyści. Wynikiem tego procesu jest pojawianie się innowacyjnych propozycji żywności nowej generacji.

Niewątpliwie zatem jednym z głównych uwarunkowań pojawienia się produktów żywności funkcjonalnej i zainteresowania konsumentów żywnością o charakterze prozdrowotnym jest pojawienie się nowych potrzeb, w tym głównie potrzeby zachowania zdrowia, profilaktyki chorób oraz poprawy jakości życia. Jednym z powodów rosnącej popularności produktów prozdrowotnych, $\mathrm{w}$ tym tych z oświadczeniami żywieniowymi lub zdrowotnymi, jest systematycznie poprawiająca się świadomość polskich konsumentów na temat ich ciała, zdrowia i wpływu tego, co spożywaja, na stan psychiczny i fizyczny. Osobom poszukującym produktów prozdrowotnych przyświecają w gruncie rzeczy podobne cele: dbanie o zdrowie i dietę, zapobieganie przedwczesnemu starzeniu się organizmu, kontrola wagi i utrzymanie szczupłej sylwetki oraz oczywiście zapobieganie chorobom cywilizacyjnym wynikającym z nieprawidłowej diety. Dla współczesnego konsumenta żywności już nie tylko jakość, bezpieczeństwo, 
cechy sensoryczne są pożądanymi wartościami. Na postrzeganie żywności przez konsumentów wpływa również coraz szersze uświadamianie związku spożywanej żywności ze zdrowiem ${ }^{1}$.

Szacunki instytucji badawczych wskazuja, że rynek produktów żywności funkcjonalnej stanowi około 5 do 30\% rynku żywności tradycyjnej - w zależności od kategorii ${ }^{2}$. W Polsce organem państwowym odpowiedzialnym za nadzór produktów opatrzonych oświadczeniami żywieniowymi i zdrowotnymi jest Główny Inspektorat Sanitarny. Analiza rejestru Głównego Inspektoratu Sanitarnego wskazuje, że do końca 2014 roku na rynku polskim zarejestrowano 2307 (w tym 1037 nadal jest w toku postępowania) wniosków o nadanie produktom oświadczeń żywieniowych i zdrowotnych ${ }^{3}$.

Tempo rozwoju rynku żywności funkcjonalnej w Europie, Stanach Zjednoczonych i Japonii było zróżnicowane. Główną kategorię żywności funkcjonalnej w Europie stanowi nabiał (46\%) i produkty zbożowe (28\%). W USA i Japonii są to napoje funkcjonalne (58\%) oraz produkty zbożowe (USA - 17\%) lub wyroby cukiernicze (Japonia - 15\%). W Polsce są to głównie soki, napoje, koncentraty napojów, produkty zbożowe oraz przetwory mleczne $e^{4}$.

W wyniku przemian technologicznych rośnie łatwość pozyskania szczegółowej informacji o preferencjach i zachowaniach konsumentów. $Z$ kolei w wyniku przemian kulturowych i zmian demograficznych rośnie świadomość, że wiedza o konsumentach do tej pory zgromadzona szybko się dezaktualizuje. Wiedza o potrzebach i zachowaniach konsumenta warunkuje osiagnięcie sukcesu w działalności przedsiębiorstwa. Najczęściej przyjmuje się, że zachowania konsumentów to proces składający się z szerokiej gamy czynników wpływających na reakcje konsumenta przed, w trakcie oraz po dokonaniu zakupu produktu/usługi. Obecnie informacje o zachowaniach polskich konsumentów na rynku produktów żywnościowych w kontekście zakupu produktów opatrzonych oświadczeniami żywieniowymi i zdrowotnymi są fragmentaryczne i często niespójne, a przez to niewystarczające. Problematyka dotycząca konsumpcji produktów żywności zawierającej tego typu oświadczenia była już szczątkowo poruszana w literaturze polskiej (zdecydowanie szerzej w zagranicznej), jednak zagadnienia postrzegania oświadczeń żywieniowych i zdrowotnych i ich wpływu na proces zakupowy konsumentów jedynie wyrywkowo tylko w literaturze zagranicznej. Dostęp-

\footnotetext{
${ }^{1}$ C. Hasler, Functional Foods: Their Role in Disease Prevention and Health Promotion, Food Technology 1998, no. 52, p. 63-70.

${ }^{2} \mathrm{http}$ ://www.portalspozywczy.pl/mleko/wiadomosci/tylko-5-proc-jogurtow-to-produkty funkcjonalne,16939.html; http://wiadomoscihandlowe.pl/2014/09/sok-zamiast-tabletki/

${ }^{3}$ http://rejestrzp.gis.gov.pl/

${ }^{4} \mathrm{http}$ ://www.portalhodowcy.pl/hodowca-drobiu/307-numer-42013/3235-zywnosc-funkcjonalnadefinicja-klasyfikcja-przeznaczenie-czesc-1
} 
ne w literaturze wyniki badań wskazują jednoznacznie, że konsumenci pragną spożywać żywność funkcjonalną z uwagi na postrzeganą nagrodę wynikająca z konsumpcji, wierząc że produkty te mogą poprawiać zdrowie i kondycję ${ }^{5}$. Zainteresowanie aspektami zdrowotnymi żywności i ich akceptacja jest w dużej mierze uwarunkowana świadomością żywieniową konsumentów 6 . Badania dotyczace stopnia zaufania do informacji na opakowaniach produktów żywnościowych prowadził przede wszystkim zespół pod kierownictwem K.G. Grunerta ${ }^{7}$. Rozumienie „health claims” i poziom świadomości żywieniowej konsumentów są szeroko dyskutowane w literaturze ${ }^{8}$. Literatura krajowa wskazuje na znaczną lukę w badanym obszarze. Jedne z nielicznych badań zostały przeprowadzone na zlecenie Europejskiej Rady Informacji o Żywności (EUFIC-European Food Information Council) na temat świadomości żywieniowej Europejczyków w 2008 roku' ${ }^{9}$ W 2009 roku przeprowadzono badanie w obszarze oceny wiedzy konsumentów na temat znakowania żywności przez dr hab. G. Krasnowską oraz dr inż. A. Salejdę z Uniwersytetu Przyrodniczego we Wrocławiu ${ }^{10}$. Inne badanie, jakie zostało przeprowadzone w Polsce, to badanie przeprowadzone przez K. Rejman oraz A. Kasperską z Uniwersytetu Warszawskiego w zakresie wartości odżywczych i zdrowotnych, jako wyznaczników przy wyborze żywności na polskim

\footnotetext{
${ }^{5}$ N. Urala, L. Lahteenmaki, Attitudes behind consumers' willingness to use functional foods, Food Quality and Preference 2004, 15; N. Urala, L. Lahteenmaki, Consumers changing attitudes towards functional foods, Food Quality and Preference 2007, 18; K. Miklavec, I. Pravst, KG. Grunert, M. Klopcic, J. Pohar, The influence of health claims and nutritional composition on consumers'yoghurt preferences, Food Quality and Preference 43, 2015, p. 26-33; S. Bialkova, L. Sasse, A. Fenko, The role of nutrition labels and advertising claims in altering consumers' evaluation and choice, Appetite 96 (2016), p. 38-46.

${ }^{6} \mathrm{~W}$. Verbeke, Consumer acceptance of functional foods: socio-demographic, cognitive and attitudinal determi-nant, Food Quality and Preference 2005, 16; B. Wansink, R.E. Westgren, M.M. Cheney, Hierarchy of nutritional knowledge that relates to the consumption of a functional food., Nutrition 2005, 21; A. Cavaliere, E.C. Ricci, A. Banterle, Nutrition and health claims: Who is interested? An empirical analysis of consumer preferences in Italy, Food Quality and Preference 41, 2015, p. 44-51.

${ }^{7}$ K.G. Grunert, J. Scholderer, M. Rogeaux, Determinants of consumer understanding of health claims. Appetite 2011, 56 (2).

${ }^{8}$ P.D. Leathwood, D.P. Richardson, P. Strater, P.M. Todd, H.C.M. van Trijp, Consumer understanding of nutrition and health claims: source of evidence, British Journal of Nutrition 2007, 98; L. Lahteenmaki, P. Lampila, K.G. Grunert, K. Boztug, O. Ueland, A. Astrom, E. Martinsdotir, Impact of healthrelated claims on the perception of other products attributes, Food Policy 2010, 35.

${ }^{9}$ K.G. Grunert, J.M. Wills, Pan-European consumer research on in-store behaviour, understanding and use of nutrition information on food labels, and nutrition knowledge. EUFIC, 2008, webinarium.

${ }^{10} \mathrm{G}$. Krasnowska, A. Salejda (in polish) Consumer knowledge about food product labeling, Food. Science. Technology. Quality, 2011, 1 (74).
} 
rynku $^{11}$. Badania dotyczące różnych aspektów konsumpcji żywności funkcjonalnej poruszał również zespół Uniwersytetu Ekonomicznego w Poznaniu prof. B. Sojkin, prof. M. Małecka, dr T. Olejniczak ${ }^{12}-$ jednak tyko w wybranych obszarach. Mimo poruszanych różnorodnych zagadnień w obszarze konsumpcji produktów żywności prozdrowotnej oraz znaczenia informacji żywieniowej w zachowaniach konsumentów - badania dotyczace wpływu na proces zakupowy wybranych informacji umieszczonych na etykiecie produktu - nie były prowadzone w polskich realiach.

W związku z nieznanym dotąd obszarem zachowań polskich konsumentów na rynku produktów funkcjonalnych zawierających oświadczenia żywieniowe i zdrowotne podjęto próbę zbadania wpływu ich treści na decyzje zakupowe konsumentów.

\section{Proces decyzyjny konsumentów na rynku produktów opatrzonych oświadczeniami żywieniowymi i zdrowotnymi}

Analiza zachowań konsumentów wobec produktów żywnościowych zawierających oświadczenia żywieniowe i zdrowotne została podjęta w badaniach konsumenckich przeprowadzonych w latach 2012-2014 w ramach projektu z działalności statutowej pt. „Rola oświadczeń żywieniowych i zdrowotnych w procesie zakupowym konsumentów". Jako badanie wstępne jakościowe przeprowadzono obserwację ukrytą $\mathrm{z}$ zastosowaniem instrumentu pomiarowego w postaci arkusza obserwacji. Obserwacja zachowań konsumentów miała miejsce w 2012 roku, w 5 placówkach handlowych, gdzie zaobserwowano w sumie 320 jednostek. Celem niniejszego badania była identyfikacja elementów procesu zakupu produktów żywnościowych opatrzonych oświadczeniami żywnościowymi i zdrowotnymi oraz określenie kategorii produktowych, których zakup poprzedzony jest zapoznaniem się z treścią etykiety. Badania właściwe przeprowadzone zostały w latach 2012 (211 respondentów), 2013 (1376 respondentów) oraz 2014 (1433 respondentów) na obszarze województwa wielkopolskiego, wśród gospodyń domowych przygotowujących posiłki i dokonujących zakupów produktów żywnościowych dla siebie i rodziny (kobiety powyżej 18. roku życia). Dobór respondentów przeprowadzony został przy wykorzystaniu metody

\footnotetext{
${ }^{11} \mathrm{~K}$. Rejman, A. Kasperska, Nutritional and health benefits as the determinants of food choice in Polish consumers, Perspectives Public Health November 2011, 131.

${ }^{12}$ B. Sojkin, M. Małecka, T. Olejniczak, M. Bakalarska, Konsument wobec innowacji produktowych na rynku żywności, wyd. Uniwersytet Ekonomiczny w Poznaniu, Poznań 2009.
} 


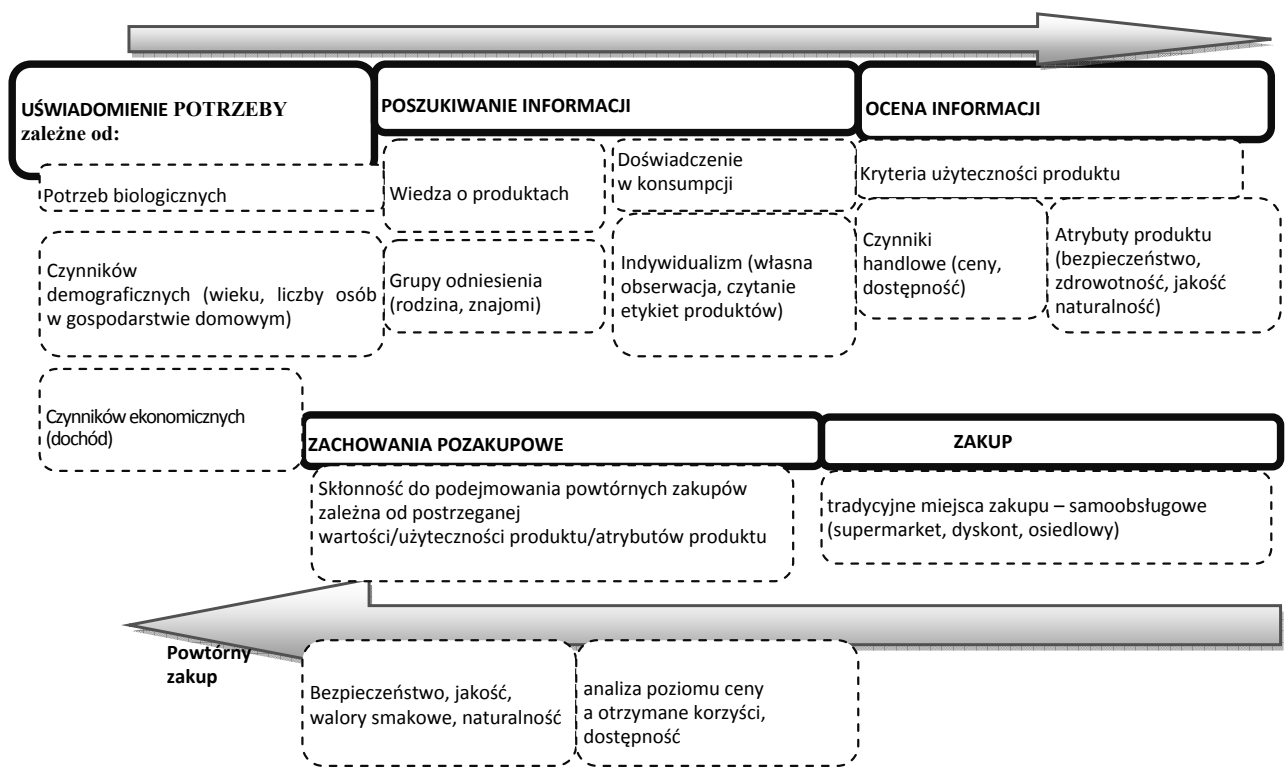

\section{Rysunek 1}

Model zakupu produktów opatrzonych oświadczeniami żywieniowymi i zdrowotnym Źródło: Opracowanie własne.

doboru kwotowego. W badaniach tych użyto technikę wywiadu bezpośredniego przy wykorzystaniu kwestionariusza wywiadu osobistego.

Do wyodrębnienia elementów mających istotne znaczenie dla identyfikacji determinant zakupu produktowych opatrzonych oświadczeniami oraz ujawnienia nieobserwowalnych (ukrytych) związków w zbiorze czynników kształtujących zachowania konsumentów wykorzystano metodę analizy czynnikowej. Jej wyniki wraz z wynikami prostych analiz badań empirycznych posłużyły do pogłębienia szczegółowości modelu procesu zakupu produktów zawierających oświadczenia na rynku żywności funkcjonalnej. W celu analizy modelu zachowań nabywczych konsumentów na rynku produktów zawierających oświadczenia żywieniowe i/lub zdrowotne punktem wyjścia powinna być identyfikacja potrzeby konsumpcji tego rodzaju produktów.

Pojawienie się potrzeby konsumpcji produktów żywnościowych zawierających na etykietach oświadczenia determinują czynniki: biologiczne (głód), ekonomiczne (dochód - osoby o większych dochodach częściej sięgają po tego rodzaju produkty) oraz demograficzne (wiek - głównie osoby między 25. a 40. rokiem życia oraz osoby starsze - po 60. roku życia, liczba osób w gospodarstwie domowym). Wyniki badania wskazują, że prawie 3/4 respondentek przeznacza na zakupy produktów żywnościowych średnio 300-400 zł tygodniowo. Taki sam udział w zakupie produktów zawierających oświadczenia żywieniowe 
i zdrowotne stanowią konsumentki w wieku 25-40 lat oraz osoby starsze, które oceniały swój stan zdrowia jako raczej zły bądź zły (ponad 60\% badanych). Ponadto konsumentki deklarowały, że jednym z powodów zakupu produktów $\mathrm{z}$ oświadczeniami była troska o zdrowie rodziny (na co wskazywała również deklarowana liczebność gospodarstwa domowego).

Podjęcie decyzji dotyczącej zaspokojenia potrzeb konsumenta rozpoczyna faza poszukiwania informacji o produktach żywnościowych zawierających oświadczenia. Najczęściej konsument styka się z marketingowymi źródłami informacji o produktach, do których zalicza reklamę żywności, sprzedaż osobistą oraz sam produkt żywnościowy dostarczający informacji poprzez swoje opakowanie. Z kolei najbardziej efektywne są źródła tzw. personalne - czyli takie, które pochodzą m.in. od rodziny, znajomych, przyjaciół lub których dostarczają np. sprzedawcy, przedstawiciele producentów i dystrybutorów żywności. $\mathrm{W}$ procesie zakupowym nowego produktu, a do takich można zaliczyć produkty funkcjonalne zawierające oświadczenia żywieniowe i zdrowotne, istotne znaczenie przypisywane jest właśnie informacjom. Tak, jak w przypadku procesu decyzyjnego na rynku w odniesieniu do produktów już znanych, konsument poszukując wariantów zaspokojenia potrzeby, rozpoczyna od wewnętrznego źródła, tj. pamięci i doświadczenia, to w przypadku produktów nowych sytuacja wygląda nieco inaczej. Źródła te bowiem okazują się niewystarczające i tu pojawia się konieczność sięgnięcia do informacji ze źródeł zewnętrznych, takich jak chociażby prasa, telewizja, ekspozycja czy informacje od rodziny, znajomych. Wyniki badań zawarte w tabeli 1 pokazują, że źródło, jakim jest rodzina i zna-

Tabela 1

Źródła informacji konsumentek o produktach zawierających oświadczeniach żywieniowe i zdrowotne

\begin{tabular}{|l|c|c|c|c|c|}
\hline $\begin{array}{c}\text { Źródło informacji o produktach } \\
\text { funkcjonalnych opatrzonych } \\
\text { oświadczeniami }\end{array}$ & $\begin{array}{c}\text { Bardzo } \\
\text { często }\end{array}$ & Często & $\begin{array}{c}\text { Trudno } \\
\text { powie- } \\
\text { dzieć }\end{array}$ & Rzadko & $\begin{array}{c}\text { Bardzo } \\
\text { rzadko }\end{array}$ \\
\hline Dostrzegam w sklepie & $12,2 \%$ & $37,3 \%$ & $19,1 \%$ & $23,2 \%$ & $8,1 \%$ \\
\hline Informacje na opakowaniu & $10,4 \%$ & $38,3 \%$ & $19,3 \%$ & $20,7 \%$ & $11,2 \%$ \\
\hline Znajomi rodzina & $9,4 \%$ & $41,1 \%$ & $17,1 \%$ & $23,6 \%$ & $8,8 \%$ \\
\hline Internet & $8,9 \%$ & $24,5 \%$ & $14,8 \%$ & $23,4 \%$ & $28,4 \%$ \\
\hline Gazetki sklepowe & $7,7 \%$ & $34,5 \%$ & $20,9 \%$ & $26,3 \%$ & $10,6 \%$ \\
\hline Artykuły w prasie czasopismach & $7,7 \%$ & $34,1 \%$ & $19,0 \%$ & $27,1 \%$ & $12,2 \%$ \\
\hline Programy kulinarne w tv & $7,6 \%$ & $31,1 \%$ & $20,0 \%$ & $29,7 \%$ & $11,6 \%$ \\
\hline Reklamy tv & $6,4 \%$ & $35,6 \%$ & $20,4 \%$ & $25,3 \%$ & $12,2 \%$ \\
\hline Lekarz dietetyk & $5,9 \%$ & $12,0 \%$ & $12,6 \%$ & $22,4 \%$ & $47,1 \%$ \\
\hline Reklamy prasowe & $4,4 \%$ & $26,2 \%$ & $23,1 \%$ & $31,7 \%$ & $14,7 \%$ \\
\hline
\end{tabular}

Źródło: Badanie własne. 
jomi pełni bardzo ważną rolę w procesie poszukiwania informacji o produktach spożywczych, a także w procesie podejmowania decyzji o zakupie. Większość z badanych wymienia to źródło na pierwszym miejscu wśród źródeł informacji na temat produktów spożywczych $(41,1 \%)$. W następnej kolejności wskazywano informacje na opakowaniu $(38,3 \%)$, dostrzeganie w sklepie $(37,3 \%)$ oraz reklamy TV $(35,6 \%)$.

Wyniki przeprowadzonego badania, które ilustruje tabela 1 wskazują, że wśród trzech najważniejszych źródeł informacji o produktach funkcjonalnych znalazły się dostrzeżenie $\mathrm{w}$ sklepie $(12,2 \%)$ oraz informacja na opakowaniu $(10,4 \%)$. W dalszej kolejności znalazły się informacje pochodzące ze źródeł nieformalnych, takich jak rodzina $(9,4 \%)$ oraz Internet $(8,9 \%)$. Najrzadziej wskazywany źródłami przez respondentki były porady lekarza/dietetyka (47,1\% korzysta z nich bardzo rzadko).

W tabeli 2 przedstawiono powody zakupu produktów zawierających oświadczenia. Zamiar zakupu produktu opatrzonego oświadczeniem żywieniowym bądź zdrowotnym i zrealizowanie go determinuje głównie atrybut zdrowotności - główny czynnik skłaniający konsumenta do zakupu tego rodzaju produktu to jego wpływ na zdrowie $(61,3 \%)$. Ważną rolę pełni tu również troska o zdrowie rodziny $(8,1 \%)$, co potwierdza wpływ liczby osób w gospodarstwie domowym na zainteresowanie produktami żywnościowymi z tego segmentu.

\section{Tabela 2}

Powody zakupu produktów opatrzonych oświadczeniami - hierarchia

\begin{tabular}{|l|c|}
\hline Powody zakupu & \% odpowiedzi \\
\hline Zależy mi na swoim zdrowiu & 61,3 \\
Nie zwracam uwagi na to & 9,7 \\
Nakazy dietetyczne & 9,7 \\
Troska o zdrowie rodziny & 8,1 \\
Bogate w minerały i witaminy & 3,2 \\
Zwracam uwagę na ceny & 1,6 \\
Smaczne & 1,6 \\
Nie da się uniknać tych oświadczeń & 1,6 \\
Namowa innych & 1,6 \\
Choroba & 1,6 \\
\hline
\end{tabular}

Źródło: Badanie własne.

Istotnym elementem $\mathrm{w}$ procesie decyzyjnym związanym $\mathrm{z}$ zakupem produktów żywnościowych zawierających oświadczenia jest postrzeganie poszczególnych atrybutów przez konsumenta. Jak wskazują wyniki badania zawarte w tabeli 3, najważniejszym atrybutem przy zakupie tego typu produktów żywnościowych są dla konsumentów bezpieczeństwo spożywanego produktu, jak 
Tabela 3

Atrybuty produktów opatrzonych oświadczeniami - hierarchia

\begin{tabular}{|l|c|}
\hline Atrybuty & Średnia* $^{*}$ \\
\hline Bezpieczeństwo & 2,99 \\
Zdrowotność & 3,12 \\
Jakość & 3,39 \\
Naturalny & 3,46 \\
Wygodny w konsumpcji & 3,62 \\
Smaczny & 3,78 \\
Innowacyjny & 3,81 \\
Specjalnie stworzony & 4,16 \\
Ryzyko alergii & 4,21 \\
Łatwo dostępny w sklepach & 4,26 \\
Atrakcyjny cenowo & 4,70 \\
Trwały & 5,03 \\
\hline
\end{tabular}

* Średnia z odpowiedzi; respondenci udzielali odpowiedzi od 1 - najważniejszy powód, do 7 - nieistotny powód.

Źródło: Badanie własne.

jego wysoka jakość oraz wpływ na zdrowie. Ponadto konsumenci postrzegają produkty zawierające oświadczenia jako produkty nieatrakcyjne cenowo, czyli drogie nietrwałe - o krótkim terminie przydatności do spożycia.

Każda decyzja podejmowana przez konsumenta jest obarczona również pewnym ryzykiem. Celem przeprowadzonego badania było również określenie ryzyka konsumenckiego determinującego zachowania zakupowe konsumentów na rynku produktów żywnościowych opatrzonych oświadczeniami żywieniowymi oraz zdrowotnymi, co w modelu zakupowym odgrywa znaczącą rolę. Rodzaj wątpliwości, z jakimi spotykają się konsumenci, przedstawia tabela 4.

\section{Tabela 4}

Rodzaj pojawiających się wątpliwości w procesie zakupu produktów żywności funkcjonalnej

\begin{tabular}{|l|c|}
\hline \multicolumn{2}{|c|}{$\begin{array}{c}\text { Ryzyko zakupowe - średnia, gdzie 1 oznacza bardzo często, } \\
5-\text { bardzo rzadko }\end{array}$} \\
\hline Mała wiedza o produkcie & 2,78 \\
\hline Niedobry smak produktów & 2,97 \\
\hline Niezbadany wpływ na zdrowie & 3,04 \\
\hline Nieładny zapach produktów & 3,05 \\
\hline Nieodpowiedni skład produktów & 3,05 \\
\hline Negatywna opinia znajomych & 3,14 \\
\hline
\end{tabular}

Źródło: Badania własne. 
Jak pokazują wcześniej przedstawione wyniki, największy obszar pojawiającego się ryzyka przy zakupie tego rodzaju produktów stanowi mała wiedza o produkcie (średnia odpowiedzi 2,78). Stosunkowo często respondentki wskazywały, że wątpliwości przedzakupowe związane są niezbadanym wpływem na zdrowie konsumpcji produktów żywności funkcjonalnej $(3,04)$. Potwierdza to brak świadomości i niewielki poziom wiedzy żywieniowej w zakresie tego segmentu żywności. Skutecznie powstrzymują przed zakupem konsumentów również obawy co do walorów sensorycznych produktów żywności funkcjonalnej - niedobry smak, niedobry zapach - średnia odpowiedz 3,05. Najmniejsze znaczenie w obrębie badanych czynników miała negatywna opinia znajomych, co może wskazywać, że przy zakupie tego rodzaju produktów żywnościowych konsumentki nie sugerują się opiniami innych bądź też nie wymieniają się opiniami w swoim otoczeniu w tym obszarze (efekt niewielkiej grupy kupujących produkty tego rodzaju).

W dalszej kolejności zbadano częstotliwość dokonywania zakupów tego rodzaju produktów żywnościowych w poszczególnych placówkach handlowych (tabela 5). Wyniki przeprowadzonych badań wskazują, że najpopularniejszym miejscem zakupu produktów żywności opatrzonej oświadczeniami żywieniowymi i zdrowotnymi jest hiper i supermarket - zakupów w tych placówkach dokonuje przeszło $90 \%$ badanych, z czego $46 \%$ często. Równie często respondenci dokonują zakupów tego rodzaju żywności w dyskontach spożywczych (42,7\%) - choć należy pamiętać, że nie w każdym dyskoncie dostępna jest szeroka oferta produktów z tej kategorii żywności. W sklepie osiedlowym często dokonuje zakupu przeszło co trzeci badany $(34,1 \%)$.

Tabela 5

Częstotliwość dokonywania zakupów żywności zawierającej oświadczenia żywieniowe i zdrowotne

\begin{tabular}{|l|c|c|c|c|c|}
\hline $\begin{array}{c}\text { Wyszczegól- } \\
\text { nienie }\end{array}$ & $\begin{array}{c}\text { Super } \\
\text { hipermarket }\end{array}$ & $\begin{array}{c}\text { Sklep } \\
\text { dyskontowy }\end{array}$ & $\begin{array}{c}\text { Sklep } \\
\text { osiedlowy }\end{array}$ & Bazar rynek & $\begin{array}{c}\text { Sklep } \\
\text { internetowy }\end{array}$ \\
\hline Często & $46,0 \%$ & $42,7 \%$ & $34,1 \%$ & $20,9 \%$ & $3,2 \%$ \\
\hline Czasami & $26,8 \%$ & $29,8 \%$ & $28,5 \%$ & $26,4 \%$ & $7,4 \%$ \\
\hline Rzadko & $17,8 \%$ & $16,6 \%$ & $23,9 \%$ & $27,6 \%$ & $14,1 \%$ \\
\hline Wcale & $9,4 \%$ & $10,9 \%$ & $13,5 \%$ & $25,1 \%$ & $75,3 \%$ \\
\hline
\end{tabular}

Źródło: Badania własne.

Ostatnim etapem procesu zakupowego konsumentów indywidualnych na rynku produktów żywnościowych opatrzonych oświadczeniami są zachowania pozakupowe. Hierarchia postrzeganych atrybutów pokazuje, że zachętą do ponownego zakupu produktu zawierającego oświadczenie żywieniowe i/lub zdrowotne będzie jego walor zdrowotny i jakościowy, ale również wygoda w konsumpcji, walory smakowe czy atrakcyjność cenowa. 


\section{Podsumowanie}

Stworzony na podstawie przeprowadzonych wyników badań model zakupu produktów żywnościowych opatrzonych oświadczeniami żywieniowymi $\mathrm{i} /$ lub zdrowotnymi (mając w pamięci jego ograniczenia) jest źródłem wiedzy dla kształtowania strategii marketingowych producentów badanych produktów. Ponadto w obliczu zwiększającej się liczby produktów zawierających tego typu treści dostarcza informacji o podstawowych elementach postępowania konsumentów na tym rynku produktów żywnościowych.

Obecnie analitycy uważają, iż istnieje wiele czynników determinujących rozwój kategorii żywności zawierającej oświadczenia żywieniowe i/lub zdrowotne ${ }^{13}$. Do najczęściej wymienianych zaliczyć można m.in. zmiany w sposobie żywienia, wzrastającą wiedzę i świadomość klientów oraz oczywiście rosnące zainteresowanie zdrowiem swoim i bliskich oraz dobrym samopoczuciem. Bardzo duże znaczenie dla rozwoju tego typu innowacyjnych produktów będzie mieć systematyczne dostarczanie potwierdzonych naukowych faktów, dotyczących prozdrowotnych wartości odżywczych poszczególnych składników odżywczych, surowców i produktów, rozwoju myśli technologicznej oraz możliwości i umiejętności projektowania nowych produktów. Na pewno duże znaczenie w rozwoju tego segmentu będą miały świadomość i pozytywne nastawienie producentów, rozwijanie przez nich wiedzy i doświadczeń oraz chęć produkowania naprawdę pomocnych dla zdrowia wyrobów, a nie tylko oferowanie marketingowo ładnie opakowanego produktu.

\section{Literatura}

BIALKOVA S., SASSE L., FENKO A., The role of nutrition labels and advertising claims in altering consumers' evaluation and choice, Appetite 96, 2016, p. 38-46.

CAVALIERE A., RICCI E.C., BANTERLE A., Nutrition and health claims: Who is interested? An empirical analysis of consumer preferences in Italy, Food Quality and Preference 41, 2015, p. 44-51.

CHILDS N.M., Functional foods and the food industry: consumer, economic and product development issues, Journal Nutraceuticals, Functional, Medial Foods 1/1997, p. 25-43.

GÓRSKA J., Żywność funkcjonalna: bliżej potrzeb klienta, Forum Mleczarskie Handel $5 / 2013(60)$.

GRUNERT K.G., SCHOLDERER J., ROGEAUX M., Determinants of consumer understanding of health claims. Appetite 2011, 56 (2).

GRUNERT K.G., WILLS J.M., Pan-European consumer research on in-store behaviour, understanding and use of nutrition information on food labels, and nutrition knowledge. EUFIC, 2008, webinarium.

\footnotetext{
${ }^{13}$ J. Górska, Żywność funkcjonalna: bliżej potrzeb klienta, Forum Mleczarskie Handel 5/2013 (60).
} 
HASLER C., Functional Foods: Their Role in Disease Prevention and Health Promotion, Food Technology 1998, no. 52, p. 63-70.

KRASNOWSKA G., SALEJDA A., (in polish) Consumer knowledge about food product labeling, Food. Science. Technology. Quality, 2011, 1 (74).

LAHTEENMAKI L., LAMPILA P., GRUNERT KG., BOZTUG K., UELAND O., ASTROM A., MARTINSDOTIR E., Impact of healthrelated claims on the perception of other products attributes, Food Policy 2010, 35.

LEATHWOOD PD., RICHARDSON DP., STRATER P., TODD PM., VAN TRIJP HCM., Consumer understanding of nutrition and health claims: source of evidence, British Journal of Nutrition 2007, 98.

MIKLAVEC K., PRAVST I., GRUNERT KG., KLOPCIC M., POHAR J., The influence of health claims and nutritional composition on consumers'yoghurt preferences, Food Quality and Preference 43, 2015, p. 26-33.

REJMAN K., KASPERSKA A., Nutritional and health benefits as the determinants of food choice in Polish consumers Perspectives, Public Health November 2011, 131.

SOJKIN B., MAŁECKA M., OLEJNICZAK T., BAKALARSKA M., Konsument wobec innowacji produktowych na rynku żywności, Wyd. Uniwersytet Ekonomiczny w Poznaniu, Poznań 2009.

URALA N., LAHTEENMAKI L., Consumers changing attitudes towards functional foods, Food Quality and Preference 2007, 18.

URALA N., LAHTEENMAKI L., Attitudes behind consumers' willingness to use functional foods, Food Quality and Preference 2004, 15.

VERBEKE W., Consumer acceptance of functional foods: sociodemographic, cognitive and attitudinal determinant, Food Quality and Preference 2005, 16.

WANSINK B., WESTGREN RE., CHENEY MM., Hierarchy of nutritional knowledge that relates to the consumption of a functional food, Nutrition 2005, 21.

http://www.portalspozywczy.pl/mleko/wiadomosci/tylko-5-proc-jogurtow-to-produkty funkcjonalne,16939.html; http://wiadomoscihandlowe.pl/2014/09/sok-zamiast-tabletki/

http://www.portalhodowcy.pl/hodowca-drobiu/307-numer-42013/3235-zywnosc-funkcjonalna-definicja-klasyfikcja-przeznaczenie-czesc-1

http://rejestrzp.gis.gov.pl/

\section{Abstrakt}

W dobie rozwoju chorób cywilizacyjnych oraz wzrostu dbałości o zdrowie konsumenci zmieniają swój schemat żywienia, czego rezultatem są między innymi poszukiwania żywności przynoszącej im określone korzyści. Wynikiem tego procesu jest pojawianie się innowacyjnych propozycji żywności, w tym produktów zawierających oświadczenia żywieniowe i zdrowotne. Wiedza o potrzebach i zachowaniach konsumenta jest przy tym bardzo istotna, gdyż warunkuje ona między innymi osiagnięcie sukcesu w działalności przedsiębiorstwa. W artykule przedstawiono propozycję modelu zakupu produktów opatrzonych oświadczeniami żywieniowymi i zdrowotnymi na podstawie zrealizowanych badań. 
Słowa kluczowe: zachowania konsumentów, proces zakupowy, oświadczenia żywieniowe, oświadczenia zdrowotne

\title{
The purchase model of food products with nutrition and health claims
}

\begin{abstract}
In the era of civilization diseases and the growth of health care consumers change their feeding scheme, resulting in searching for food products bringing them certain benefits. In consequence, innovative types of food emerge, including products with nutrition and health claims. The knowledge about the consumer's needs and behavior is very important for the enterprises, because it determines, among others, success in business. The article proposes a purchase model of products bearing nutrition and health claims which was based on own carried out research.
\end{abstract}

Key words: consumer behavior, purchasing process, nutrition claims, health claims 